\title{
9. LATE NEOGENE OXYGEN-ISOTOPE STRATIGRAPHY AND FLUX RATES OF TERRIGENOUS SEDIMENTS AT HOLE 544B OFF MOROCCO ${ }^{1}$
}

\author{
R. Stein and M. Sarnthein ${ }^{2}$, Geologisch-Paläontologisches Institut, Universität Kiel
}

\begin{abstract}
At DSDP Hole 544B, oxygen-isotope stratigraphy, carbonate proportion, clay mineralogy, and (terrigenous) grainsizes show short-term ("Milankovitch-type") sediment cycles from $5.1 \mathrm{~m} . \mathrm{y}$. to the present and fairly uniform conditions of deposition before this date. The cycles are superimposed by two large-scale shifts of sediment composition and flux parallel to distinct changes of the average benthos $\delta^{18} \mathrm{O}$ composition (up to $0.7 \%$ ). The shifts coincide with major hiatuses from 1.05 to 1.65 and from 2.4 to $4.5 \mathrm{~m}$.y. and can be correlated with specific events of the global climatic evolution. The marked increase in the proportion of chlorite and in the grain-sizes of terrigenous matter near 2.4 m.y. may reflect increased physical weathering and denudation of the Atlas Mountains and the lowering of sea level. These hiatuses were probably formed by strengthened contour currents that also may have caused the reduction of both terrigenous and calcium-carbonate flux rates during the Brunhes Magnetic Epoch.
\end{abstract}

\section{INTRODUCTION}

Deep sea sediments can provide a continuous record of paleoceanographic evolution as well as of the paleoclimates of adjacent continents. Such information was obtained from DSDP Hole 544B, drilled at the northern end of a "circum-Sahara" transect of a number of DSDP sites offshore northwest Africa (Fig. 1). The hole was drilled on the seaward margin of a structural high on the northwestern slope of the Mazagan Plateau, Morocco $\left(33^{\circ} 46.13^{\prime} \mathrm{N}, 09^{\circ} 24.29^{\prime} ; 3600 \mathrm{~m}\right.$ water depth; Hinz et al., 1982). Its position approximately marks the latitude of the present climatic boundary between Mediterranean scrub and steppe vegetation belts, i.e., a region dominated by westerly winds during the winter and trade winds during the summer (Agwu and Beug, 1982; Seibold, 1982).

The $39.3 \mathrm{~m}$ sediment section, which ranges from Pleistocene to late Miocene and includes two major hiatuses, was retrieved by hydraulic piston coring. Although much less disturbed than samples obtained by rotary drilling, the present (hydraulic piston) core section is partly discontinuous and disturbed because of cracked core liners and incomplete sediment recovery of the cores (see site chapter, this volume). Nevertheless, undisturbed 20 to $100 \mathrm{~cm}$ thick sedimentary cycles can be clearly observed from regular color fluctuations in the majority of the core profile (Fig. 2). These cycles indicate a short-term fluctuating paleoenvironmental influence on sediments superimposed upon long-term sediment variations. Understanding the cause of both of these fluctuations is the objective of this study. We studied approximately 200 samples taken from the $39.3 \mathrm{~m}$ section, that is, 1 sample per $20 \mathrm{~cm}$ or approximately $13,000 \mathrm{yr}$. on the average, including the hiatuses. However, because the sampling density is discontinuous, we were able to focus

\footnotetext{
${ }^{1}$ Hinz, K., Winterer, E. L., et al., Init. Repts. DSDP, 79: Washington (U.S. Govt. Printing Office).

Address: Geologisch-Paläontologisches Institut, Universităt Kiel, Olshausenstr. 40/60, D-2300 Kiel, Federal Republic of Germany.
}

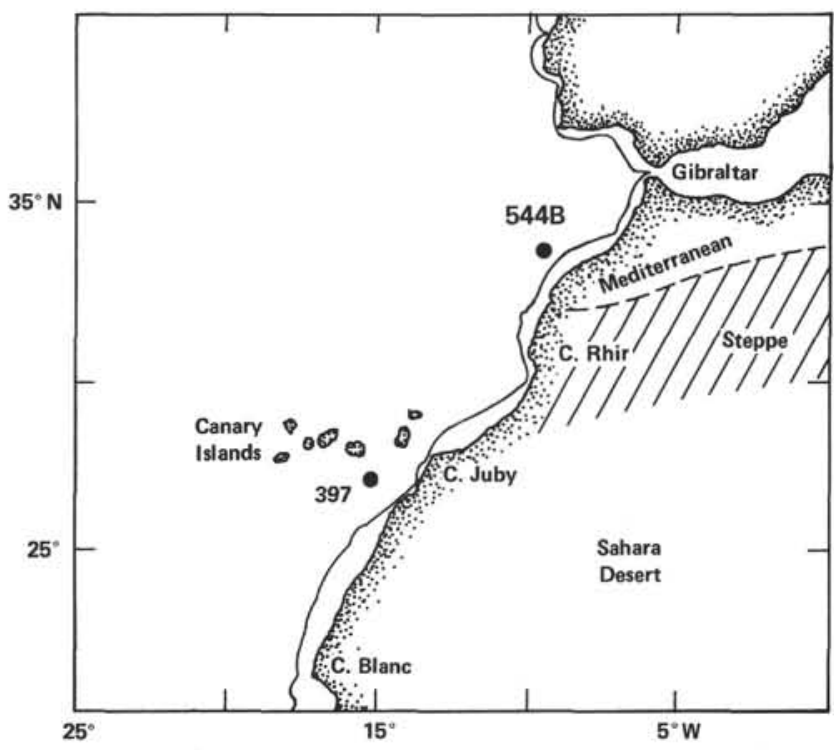

Figure 1. Location map for Hole 544B and Site 397. Mediterranean zone of modern Mediterranean climate.

on certain sections of the core with an optimum coverage of up to 14 samples per meter (Fig. 2).

\section{METHODS}

One hundred-one samples were carefully selected on the basis of a personal, visual reexamination of the Hole 544B cores (Fig. 2). J. Channell (Lamont-Doherty Geological Observatory, Palisades, NY) provided an additional 114 samples. The 215 samples were washed through a $63 \mu \mathrm{m}$ sieve. The carbonate content was determined from a subsample of the $<63 \mu \mathrm{m}$ fraction by infrared absorption of $\mathrm{CO}_{2}$ released by phosphoric acid treatment. The sediment coarse fraction ( $>63 \mu \mathrm{m})$ was dried at $40^{\circ} \mathrm{C}$. Four benthic foraminiferal species in the $>250 \mu \mathrm{m}$ sediment fraction (Uvigerina peregrina, $U$. finisterrensis, Cibicidoides wuellerstorfi, Pyrgo murrhina; determinations according to Lutze, 1979) were picked and samples of 10 to 15 specimens prepared for ${ }^{13} \mathrm{C} /{ }^{12} \mathrm{C}$ and ${ }^{18} \mathrm{O} /{ }^{16} \mathrm{O}$ isotopic measurements (for details, see Ganssen, 1983). Isotopic analyses were performed using a MICROMASS 602D at the ${ }^{14} \mathrm{C}$ laboratory of the Institut für Kernphysik, Universität Kiel.

The sediment fraction $<63 \mu \mathrm{m}$ was treated successively, with hydrogen peroxide and acetic acid in order to remove both organic mat- 

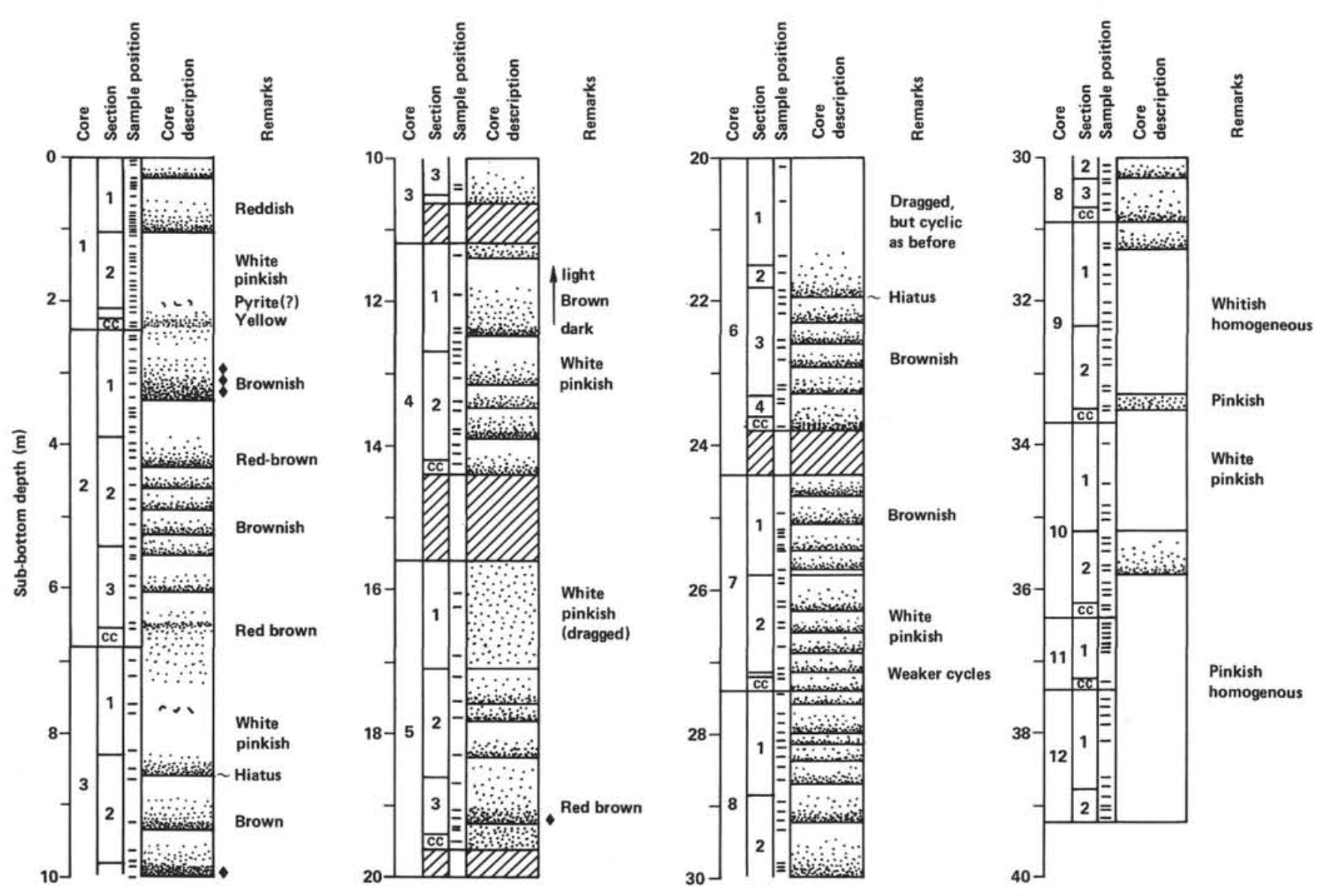

Figure 2. Description of color cycles contained in Hole 544B sediments. $\bullet=$ bioturbation. Hachured areas indicate gaps.

ter and carbonate. The carbonate-free sediment fraction was analyzed for its grain-size distribution by a SediGraph 5000D (Stein, in press) and separated into silt ( $>6 \mu \mathrm{m}$ and 2-6 $\mu \mathrm{m})$ and clay fraction $(<2$ $\mu \mathrm{m}$ ) by the Atterberg method (Müller, 1967). Silt fractions 6-12, 12 $20,20-25,25-32,32-40$, and $>40 \mu$ m were studied microscopically by smear slide counts for biogenic opal content (method by Koopmann, 1981). Clay minerals from the clay fraction were analyzed by X-ray diffraction (Philips diffractometer PW 1050 with a constant potential generator PW 1730 using a cobalt target) following Biscaye (1965) and Lange (1982).

\section{RESULTS AND DISCUSSION}

\section{Stratigraphy}

All stable isotope measurements (three were rejected because of small sample size) are shown in Table 1. For some samples, parallel measurements of the isotopes of the three different genera (Table 1) allow a comparison of their departure from the oxygen-isotope equilibrium and confirm the estimated departures of Shackleton (1973). Accordingly, the $\delta^{18} \mathrm{O}$ values listed in Table 1 have been adjusted to Uvigerina sp by $\Delta=+0.64 \% 0$ for Cibicides wuellerstorfi and $\Delta=+0.000 \%$ for Pyrgo murrhina for their stratigraphic use (Fig. 3B). The scatter for the correlation of Pyrgo versus Uvigerina $\delta^{18} \mathrm{O}$ values does not exceed the $C$. wuellerstorf $i$ versus Uvigerina $\delta^{18} \mathrm{O}$ values (Blanc, 1981; Stein, 1984). This correction procedure was only partially applied for the carbon isotope composition because of nonlinear interspecific isotopic differences between $P$. murrhina and the other three species (compare Shackleton and Cita, 1979; Ganssen, 1983) (Figs. 3D, 3E). The offset of $\delta^{13} \mathrm{C}$ of $U$. perigrina from $C$. wuellerstorf $i$ is constant approximately $-0.90 \%$ Shackleton and Opdyke, 1973).

The $\delta^{18} \mathrm{O}$ record of Hole 544B (Fig. 3B) is composed of three major sections listed in Table 2, each of which are separated by fairly sharp shifts of the long-term $\left(10^{6}\right.$ yr.) mean level of oxygen isotopic composition. The range of short-term ( $10^{4}$ to $10^{5}$ yr.) oxygen isotopic fluctuations is low in stratigraphic section II (except for one extreme glacial phase at $13.8 \mathrm{~m}$ sub-bottom depth) and in the lower part of section III. It is high in the middle part of section III and is very high in section I (Table 2). These differences apparently are not controlled by the difference in sampling density which is particularly high in most parts of the stratigraphic sections (Fig. 2).

The Shipboard Party (Site 544 site chapter, this volume) provided a preliminary biostratigraphy of Hole 544B for the late Neogene and early Pleistocene. This biostratigraphy was supplemented and modified by biostratigraphic observations by Martini, Pflaumann, and Samtleben (pers. comm., 1983). The observed stratigraphic markers, listed in Table 3, show the age of the total sediment section ranging between 0.1 and 5.6 m.y.

Magnetostratigraphy (Channell, this volume) provided only fragmentary information because of the disturbed sediment structures of some cores. The observed magnetic anomalies and events are shown in Figures 3A 
Table 1. Oxygen and carbon isotopic data from Hole 544B.

\begin{tabular}{|c|c|c|c|c|}
\hline \multirow{2}{*}{$\begin{array}{l}\text { Core-section } \\
\text { (level in cm) }\end{array}$} & \multirow{2}{*}{$\begin{array}{l}\text { Sub-bottom } \\
\text { depth (m) }\end{array}$} & \multirow[b]{2}{*}{ No. } & $\delta^{18} \mathrm{O}$ & \multirow{2}{*}{$\begin{array}{l}\delta^{13} \mathrm{C} \\
\text { DB) }\end{array}$} \\
\hline & & & $(\% 0$ & \\
\hline $1-1,9$ & 0.07 & 1 & 3.79 & 1.48 \\
\hline $1-1,14$ & 0.10 & 1 & 3.74 & 0.24 \\
\hline $1-1,39$ & 0.28 & 1 & 5.07 & 0.39 \\
\hline $1-1,50$ & 0.35 & 1 & 4.99 & 0.95 \\
\hline x $1-1,59$ & 0.42 & 1 & 4.39 & 0.92 \\
\hline$\times 1-1,59$ & 0.42 & 2 & 4.58 & -0.26 \\
\hline × $1-1,59$ & 0.42 & 6 & 3.73 & 0.74 \\
\hline $1-1,66$ & 0.47 & 1 & 3.95 & 0.86 \\
\hline $1-1,76$ & 0.54 & 1 & 4.14 & 0.44 \\
\hline $1-1,95$ & 0.67 & 1 & 3.92 & 0.67 \\
\hline $1-1,111$ & 0.78 & 4 & 4.72 & -0.59 \\
\hline x $1-1,119$ & 0.83 & 1 & 4.13 & 0.68 \\
\hline x $1-1,119$ & 0.83 & 2 & 4.37 & -0.61 \\
\hline x $1-1,119$ & 0.83 & 6 & 3.38 & 0.75 \\
\hline $1-1,122$ & 0.86 & 4 & 4.31 & -0.34 \\
\hline $1-1,126$ & 0.88 & 1 & 4.27 & 0.63 \\
\hline $1-1,137$ & 0.96 & 1 & 4.07 & 1.21 \\
\hline $1-1,145$ & 1.02 & 1 & 4.86 & 1.21 \\
\hline x $1-2,2$ & 1.05 & 1 & 4.50 & 0.71 \\
\hline x $1-2,2$ & 1.05 & 2 & 4.30 & -0.49 \\
\hline$x \quad 1-2,2$ & 1.05 & 6 & 3.12 & 0.63 \\
\hline $1-2,5$ & 1.09 & 1 & 3.77 & 1.35 \\
\hline $1-2,30$ & 1.26 & 1 & 4.25 & 2.07 \\
\hline $1-2,41$ & 1.34 & 1 & 3.91 & 1.81 \\
\hline $1-2,54$ & 1.43 & 4 & 4.45 & -0.21 \\
\hline $1-2,67$ & 1.52 & 2 & 4.35 & -0.29 \\
\hline $1-2,83$ & 1.63 & 4 & 4.31 & 0.02 \\
\hline $1-2,102$ & 1.76 & 6 & 2.97 & 1.13 \\
\hline $1-2,108$ & 1.80 & 1 & 3.49 & 1.25 \\
\hline $1-2,112$ & 1.83 & 6 & 2.72 & 1.05 \\
\hline $1-2,130$ & 1.95 & 6 & 2.97 & 0.96 \\
\hline $1-2,136$ & 2.00 & 6 & 3.16 & 1.04 \\
\hline $1-3,1$ & 2.10 & 1 & 4.20 & 2.04 \\
\hline $1-3,11$ & 2.17 & 1 & 4.50 & 1.81 \\
\hline $1-C, 9$ & 2.33 & 1 & 4.69 & 1.33 \\
\hline $1-C, 18$ & 2.39 & 1 & 5.15 & 1.17 \\
\hline $2-1,20$ & 2.61 & 1 & 4.65 & 1.94 \\
\hline $2-1,26$ & 2.67 & 6 & 3.17 & 0.84 \\
\hline $2-1,41$ & 2.82 & 6 & 3.18 & 0.54 \\
\hline $2-1,54$ & 2.95 & 4 & 4.71 & -0.94 \\
\hline $2-1,59$ & 3.00 & 1 & 4.69 & 0.34 \\
\hline $2-1,108$ & 3.49 & 6 & 3.22 & 0.39 \\
\hline $2-1,113$ & 3.54 & 1 & 3.87 & 1.58 \\
\hline $2-1,118$ & 3.59 & 1 & 4.37 & 0.86 \\
\hline $2-1,134$ & 3.75 & 1 & 4.62 & 1.65 \\
\hline $2-1,146$ & 3.87 & 1 & 4.31 & 1.86 \\
\hline $2-2,7$ & 4.08 & 1 & 4.39 & 1.21 \\
\hline $2-2,26$ & 4.17 & 1 & 3.93 & 1.19 \\
\hline $2-2,32$ & 4.33 & 4 & 4.05 & -0.69 \\
\hline $2-2,64$ & 4.55 & 1 & 4.60 & 1.47 \\
\hline $2-2,85$ & 4.76 & 1 & 4.18 & 1.75 \\
\hline $2-2,96$ & 4.87 & 4 & 4.34 & -0.02 \\
\hline $2-2,124$ & 5.15 & 1 & 4.25 & 1.44 \\
\hline $2-2,138$ & 5.29 & 2 & 4.71 & -0.36 \\
\hline $2-3,2$ & 5.43 & 1 & 4.50 & 1.81 \\
\hline $2-3,3$ & 5.54 & 1 & 4.67 & 1.70 \\
\hline $2-3,16$ & 5.57 & 1 & 3.87 & 2.05 \\
\hline $2-3,40$ & 5.81 & 3 & 3.44 & 0.06 \\
\hline $2-3,53$ & 5.94 & 1 & 3.66 & 1.44 \\
\hline $2-3,106$ & 6.47 & 2 & 4.31 & -0.14 \\
\hline 2-C, 4 & 6.55 & 1 & 4.55 & 2.06 \\
\hline $3-1,40$ & 7.21 & 2 & 4.70 & -0.86 \\
\hline $3-1,77$ & 7.58 & 3 & 5.06 & -0.77 \\
\hline $3-1,92$ & 7.73 & 1 & 4.81 & 1.84 \\
\hline $3-1,143$ & 8.24 & 1 & 4.60 & 1.72 \\
\hline $3-1,19$ & 8.50 & 1 & 4.98 & 1.27 \\
\hline $3-2,35$ & 8.66 & 1 & 4.09 & 1.73 \\
\hline $3-2,94$ & 9.25 & 1 & 4.40 & 1.45 \\
\hline
\end{tabular}

Table 1. (Continued).

\begin{tabular}{|c|c|c|c|c|}
\hline $\begin{array}{l}\text { Core-section } \\
\text { (level in } \mathrm{cm})\end{array}$ & $\begin{array}{c}\text { Sub-bottom } \\
\text { depth (m) }\end{array}$ & No. & $\begin{array}{r}\delta^{18} \mathrm{O} \\
(\% 0\end{array}$ & $\begin{array}{l}\delta^{13} \mathrm{C} \\
\mathrm{PDB})\end{array}$ \\
\hline $3-2,132$ & 9.63 & 1 & 3.62 & 1.51 \\
\hline $3-2,147$ & 9.78 & 1 & 3.73 & 1.44 \\
\hline $3-3,5$ & 9.86 & 2 & 3.60 & -0.33 \\
\hline $3-3,18$ & 9.99 & 1 & 4.02 & 1.67 \\
\hline $3-3,58$ & 10.39 & 3 & 4.11 & -0.08 \\
\hline $3-3,65$ & 10.46 & 1 & 4.02 & 1.60 \\
\hline $3-C, 11$ & 10.64 & 1 & 4.32 & 1.54 \\
\hline $4-1,16$ & 11.37 & 1 & 3.77 & 1.83 \\
\hline $4-1,71$ & 11.92 & 1 & 3.95 & 1.45 \\
\hline $4-1,122$ & 12.43 & 1 & 4.11 & 1.68 \\
\hline $4-1,125$ & 12.46 & 1 & 4.20 & 0.68 \\
\hline $4-1,136$ & 12.57 & 2 & 3.60 & -0.53 \\
\hline $4-1,146$ & 12.67 & 2 & 3.76 & -0.51 \\
\hline $4-2,6$ & 12.77 & 2 & 3.77 & -0.62 \\
\hline$x 4-2,16$ & 12.87 & 2 & 3.62 & -0.52 \\
\hline $4-2,36$ & 13.07 & 4 & 3.70 & -0.28 \\
\hline $4-2,111$ & 13.82 & 1 & 4.82 & 1.38 \\
\hline $4-2,114$ & 13.85 & 1 & 4.31 & 1.37 \\
\hline $4-2,128$ & 13.99 & 1 & 3.90 & 1.17 \\
\hline $4-2,141$ & 14.12 & 4 & 3.63 & -0.36 \\
\hline 4-C, 6 & 14.27 & 1 & 3.81 & 1.12 \\
\hline $5-1,45$ & 16.05 & 2 & 3.68 & -0.16 \\
\hline $5-1,64$ & 16.25 & 2 & 3.80 & -0.08 \\
\hline $5-1,132$ & 16.93 & 2 & 3.76 & 0.10 \\
\hline $5-2,11$ & 17.22 & 2 & 3.75 & -0.18 \\
\hline $5-2,44$ & 17.55 & 2 & 3.69 & -0.29 \\
\hline $5-2,67$ & 17.78 & 2 & 3.83 & -0.04 \\
\hline $5-2,118$ & 18.29 & 1 & 4.02 & 1.64 \\
\hline $5-3,8$ & 18.69 & 1 & 4.18 & 1.35 \\
\hline $5-3,46$ & 19.07 & 1 & 4.04 & 1.31 \\
\hline $5-3,56$ & 19.17 & 1 & 3.81 & 1.24 \\
\hline $5-3,73$ & 19.34 & 2 & 3.62 & -0.73 \\
\hline $5-3,75$ & 19.36 & 1 & 3.94 & 0.99 \\
\hline $5-C, 9$ & 19.50 & 1 & 3.62 & 1.32 \\
\hline $6-1,14$ & 20.15 & 2 & 3.77 & -0.15 \\
\hline $6-1,62$ & 20.63 & 1 & 3.91 & 1.05 \\
\hline $6-1,137$ & 21.38 & 1 & 4.13 & 1.36 \\
\hline $6-2,11$ & 21.62 & 1 & 3.83 & 1.73 \\
\hline $6-3,6$ & 21.87 & 1 & 3.71 & 1.74 \\
\hline $6-3,13$ & 21.94 & 1 & 4.11 & 1.26 \\
\hline $6-3,25$ & 22.06 & 1 & 3.47 & 1.47 \\
\hline $6-3,37$ & 22.18 & 1 & 3.35 & 1.09 \\
\hline $6-3,75$ & 22.56 & 1 & 3.39 & 0.79 \\
\hline $6-3,83$ & 22.64 & 1 & 3.58 & 0.90 \\
\hline $6-3,102$ & 22.83 & 2 & 2.97 & -0.34 \\
\hline $6-3,137$ & 23.18 & 1 & 3.35 & 1.87 \\
\hline $6-3,144$ & 23.25 & 1 & 2.92 & 0.80 \\
\hline $6-4,8$ & 23.37 & 1 & 3.09 & 0.90 \\
\hline $6-4,8$ & 23.37 & 4 & 3.08 & -0.03 \\
\hline $6-4,13$ & 23.44 & 1 & 3.52 & 2.28 \\
\hline $6-C, 13$ & 23.74 & 2 & 2.94 & -0.23 \\
\hline $7-1,83$ & 25.17 & 1 & 2.84 & 1.18 \\
\hline $7-1,106$ & 25.38 & 2 & 3.25 & -0.33 \\
\hline $7-1,110$ & 25.42 & 2 & 3.56 & -0.55 \\
\hline $7-1,115$ & 25.46 & 4 & 3.70 & -0.38 \\
\hline $7-1,144$ & 25.73 & 1 & 3.63 & 1.66 \\
\hline $7-2,6$ & 25.84 & 1 & 3.97 & 1.66 \\
\hline $7-2,15$ & 25.92 & 2 & 3.46 & -0.18 \\
\hline $7-2,42$ & 26.17 & 1 & 3.46 & 2.20 \\
\hline $7-2,52$ & 26.26 & 1 & 3.35 & 2.35 \\
\hline $7-2,110$ & 26.79 & 6 & 2.59 & 1.03 \\
\hline $7-2,142$ & 27.09 & 1 & 3.86 & 2.07 \\
\hline $7-3,1$ & 27.17 & 6 & 2.20 & 0.90 \\
\hline $8-1,59$ & 27.98 & 6 & 2.05 & 0.83 \\
\hline $8-1, .71$ & 28.10 & 1 & 3.42 & 2.15 \\
\hline $8-1,82$ & 28.20 & 2 & 3.62 & -0.24 \\
\hline $8-1,110$ & 28.47 & 2 & 3.62 & -0.51 \\
\hline $8-1,129$ & 28.66 & 1 & 3.50 & 1.81 \\
\hline
\end{tabular}


Table 1. (Continued).

\begin{tabular}{|c|c|c|c|c|}
\hline \multirow{2}{*}{$\begin{array}{l}\text { Core-section } \\
\text { (level in } \mathrm{cm} \text { ) }\end{array}$} & \multirow{2}{*}{$\begin{array}{l}\text { Sub-bottom } \\
\text { depth (m) }\end{array}$} & \multirow[b]{2}{*}{ No. } & \multicolumn{2}{|c|}{$\delta^{18} \mathrm{O} \quad \delta^{13} \mathrm{C}$} \\
\hline & & & & $\left.{ }_{0} \mathrm{PDB}\right)$ \\
\hline $8-2,8$ & 28.94 & 1 & 2.68 & 0.47 \\
\hline $8-2,35$ & 29.20 & 2 & 3.23 & -0.38 \\
\hline $8-2,50$ & 29.34 & 2 & 3.23 & -0.25 \\
\hline $8-2,71$ & 29.64 & 2 & 3.12 & -0.02 \\
\hline $8-2,96$ & 29.79 & 1 & 2.92 & 1.24 \\
\hline $8-2,104$ & 29.97 & 1 & 3.13 & 1.55 \\
\hline $8-2,131$ & 30.13 & 1 & 3.54 & 0.97 \\
\hline $8-2,139$ & 30.20 & 1 & 3.61 & 1.36 \\
\hline $8-3,2$ & 30.33 & 2 & 3.09 & -0.32 \\
\hline $8-3,5$ & 30.36 & 1 & 3.16 & 1.55 \\
\hline $8-3,23$ & 30.53 & 4 & 2.67 & -0.25 \\
\hline $8-3,34$ & 30.64 & 1 & 3.30 & 1.24 \\
\hline $9-1,37$ & 31.27 & 1 & 2.89 & 1.28 \\
\hline $9-1,59$ & 31.49 & 1 & 3.12 & 1.15 \\
\hline $9-1,76$ & 31.65 & 4 & 3.07 & -0.47 \\
\hline $9-1,88$ & 31.77 & 4 & 3.05 & -0.28 \\
\hline $9-1,115$ & 32.03 & 4 & 3.21 & -0.05 \\
\hline $9-1,130$ & 32.18 & 2 & 3.10 & 0.00 \\
\hline $9-1,143$ & 32.30 & 4 & 2.98 & -0.47 \\
\hline $9-2,5$ & 32.42 & 1 & 3.23 & 1.67 \\
\hline $9-2,28$ & 32.65 & 5 & 3.10 & -0.38 \\
\hline $9-2,46$ & 32.82 & 2 & 3.10 & -0.28 \\
\hline $9-2,54$ & 32.90 & 1 & 3.54 & 1.71 \\
\hline $9-2,84$ & 33.19 & 1 & 3.62 & 1.74 \\
\hline $9-2,91$ & 33.26 & 1 & 3.07 & 2.16 \\
\hline $9-C, 4$ & 33.53 & 1 & 3.40 & 2.02 \\
\hline $10-1,25$ & 33.98 & 1 & 3.21 & 1.62 \\
\hline $10-1,85$ & 34.56 & 1 & 3.46 & 1.79 \\
\hline $10-1,114$ & 34.85 & 1 & 3.39 & 2.13 \\
\hline $10-1,126$ & 34.96 & 1 & 3.31 & 1.80 \\
\hline $10-1,133$ & 35.04 & 1 & 3.35 & 1.74 \\
\hline $10-2,7$ & 35.28 & 6 & 2.54 & 0.60 \\
\hline $10-2,16$ & 35.37 & 1 & 3.57 & 1.11 \\
\hline $10-2,28$ & 35.49 & 1 & 3.34 & 1.92 \\
\hline $10-2,47$ & 35.68 & 1 & 3.38 & 1.95 \\
\hline $10-2,72$ & 35.93 & 1 & 3.33 & 1.59 \\
\hline $10-2,88$ & 36.09 & 1 & 3.32 & 1.72 \\
\hline $11-1,36$ & 36.65 & 1 & 3.02 & 1.59 \\
\hline $11-1,73$ & 36.89 & 1 & 3.33 & 2.29 \\
\hline $12-1,48$ & 37.88 & 1 & 3.45 & 1.99 \\
\hline $12-1,74$ & 38.13 & 1 & 3.41 & 1.99 \\
\hline $12-1,124$ & 38.62 & 5 & 3.01 & -0.18 \\
\hline $12-1,138$ & 38.75 & 5 & 3.04 & -0.30 \\
\hline $12-1,143$ & 38.80 & 2 & 2.98 & -0.43 \\
\hline $12-2,4$ & 38.91 & 2 & 2.96 & -0.29 \\
\hline $12-2,21$ & 39.08 & 1 & 3.67 & 1.91 \\
\hline $12-2,40$ & 39.27 & 1 & 3.39 & 1.76 \\
\hline
\end{tabular}

Note: $1=$ Pyrgo murrhina, $2=$ Uvigerina peregrina, $3=U$. finisterrensis, $4=U$. peregrina and $U$. finisterrensis, $5=$ Uvigerina $s p ., \quad 6=$ Cibicidoides wuellerstorfi. $\mathrm{x}$ refers to parallel analyses of samples from different species.

and 4. The identification of the topmost Brunhes Epoch (normal), followed by the Matuyama Epoch (reversed) and the Jaramillo Event below, is fairly well substantiated given the dominant occurrence of $E$. huxleyi below $0.1 \mathrm{~m}$ and the LAD of $P$. lacunosa below $1.80 \mathrm{~m}$ subbottom depth (Fig. 4). The following normal zone from 9.30 to $13.1 \mathrm{~m}$ sub-bottom depth may be assigned to the Olduvai Event because of the FAD of G. truncatulinoides at $11.37 \mathrm{~m}$ depth. The magnetic reversals near 22.3 $\mathrm{m}$ depth and the reversed zones down to $31.0 \mathrm{~m}$ depth are recognized as the Gilbert Epoch based on the occurrence of $G$. margaritae, $G$. nepenthes, and nannofossil
Zone NN12 (Table 3, Fig. 4) (pers. comm., Martini, Pflaumann, and Samtleben). Figure 4 summarizes the bio-, isotope-, and magnetostratigraphic evidence in a tentative age-depth diagram. Thus, the time range of the stratigraphic hiatus near $8.70 \mathrm{~m}$ sub-bottom depth is still somewhat preliminary. This stratigraphic gap can be clearly observed from an erosional sedimentary structure in the core as depicted in Figure 5. Surprisingly, the major stratigraphic gap at $22.10 \mathrm{~m}$ depth does not coincide with the distinct erosional feature in the core near 21.95 $\mathrm{m}$, but only with a minor structure and color change somewhat below (Fig. 5). It is interesting to note that the upper time limits of the two hiatuses almost precisely match the ages of two events of submarine erosion at nearby Site 397 (near $27^{\circ}$ N, Fig. 1; Sarnthein et al., 1982, modified after Hamilton, 1979; Cita and Ryan, 1979). As can be seen in Figure 4, the bulk sedimentation rates at Hole 544B range from 0.54 to $1.75 \mathrm{~cm}$ per 1000 yrs.

The two most prominent shifts in the mean $\delta^{18} \mathrm{O}$ level near $8.70 \mathrm{~m}$ and $22.10 \mathrm{~m}$ depth coincide with the positions of the two hiatuses (1.05 to 1.65 and 2.4 to $4.5 \mathrm{~m}$.y., respectively; Fig. 3B). A further (minor) shift in the mean oxygen isotopic composition occurs near $32.8 \mathrm{~m}$ depth, i.e., at about $5.2 \mathrm{~m}$.y. at the end of the Messinian salinity crisis (Fig. 3B). For further discussion of the oxygen isotope curve, see Stein (1984), and Stein and Sarnthein (in press).

\section{Sediment Cycles and Flux Rates}

Cyclic color changes mark the majority of the core profile at Hole 544B and may indicate a short-term fluctuating sedimentary regime (Fig. 2). The ranges of thickness and duration of the cycles are summarized for the different stratigraphic intervals of the profile in Table 4. Table 4 shows long lasting cycles in the range of about 200,000 yr. during the Brunhes Magnetic Epoch and much shorter cycles of 19,000 to 65,000 yr. down to 31.3 m sub-bottom depth, i.e., near 5.1 m.y. Despite the wide scatter in duration, which is due to the insufficiently precise chronology, these intervals largely resemble solar insolation cycles (Berger, 1978). No cycles could be identified below $31.3 \mathrm{~m}$ sub-bottom depth, i.e., prior to $5.1 \mathrm{~m} . \mathrm{y}$.

Many of the visually determined sediment cycles are paralleled by numerous fluctuations in the carbonate content as shown in Figures $3 \mathrm{C}$ and 6 . Their range and mean levels are listed in Table 2 . The majority of the carbonate fluctuations also parallels the oxygen isotopic curve (with high carbonate values corresponding to light isotopic ratios) above $22.1 \mathrm{~m}$ sub-bottom depth, and shows a less pronounced, but reversed correlation below (details in Stein, 1984). The sediment fraction coarser than $63 \mu \mathrm{m}$ (Fig. 6), which essentially consists of foraminifers (i.e, calcium carbonate), varies cyclically between 3 and $27 \%$ in the upper section of Hole 544B, between 3 and $17 \%$ between $8.70 \mathrm{~m}$ and $22.1 \mathrm{~m}$ sub-bottom depth, and between 0 and $7.5 \%$ below $22.1 \mathrm{~m}$ sub-bottom depth. In general, high carbonate values parallel low coarse fraction percentages of the acid insoluble, carbonate-free sediment residue (Fig. 6, \% ter- 

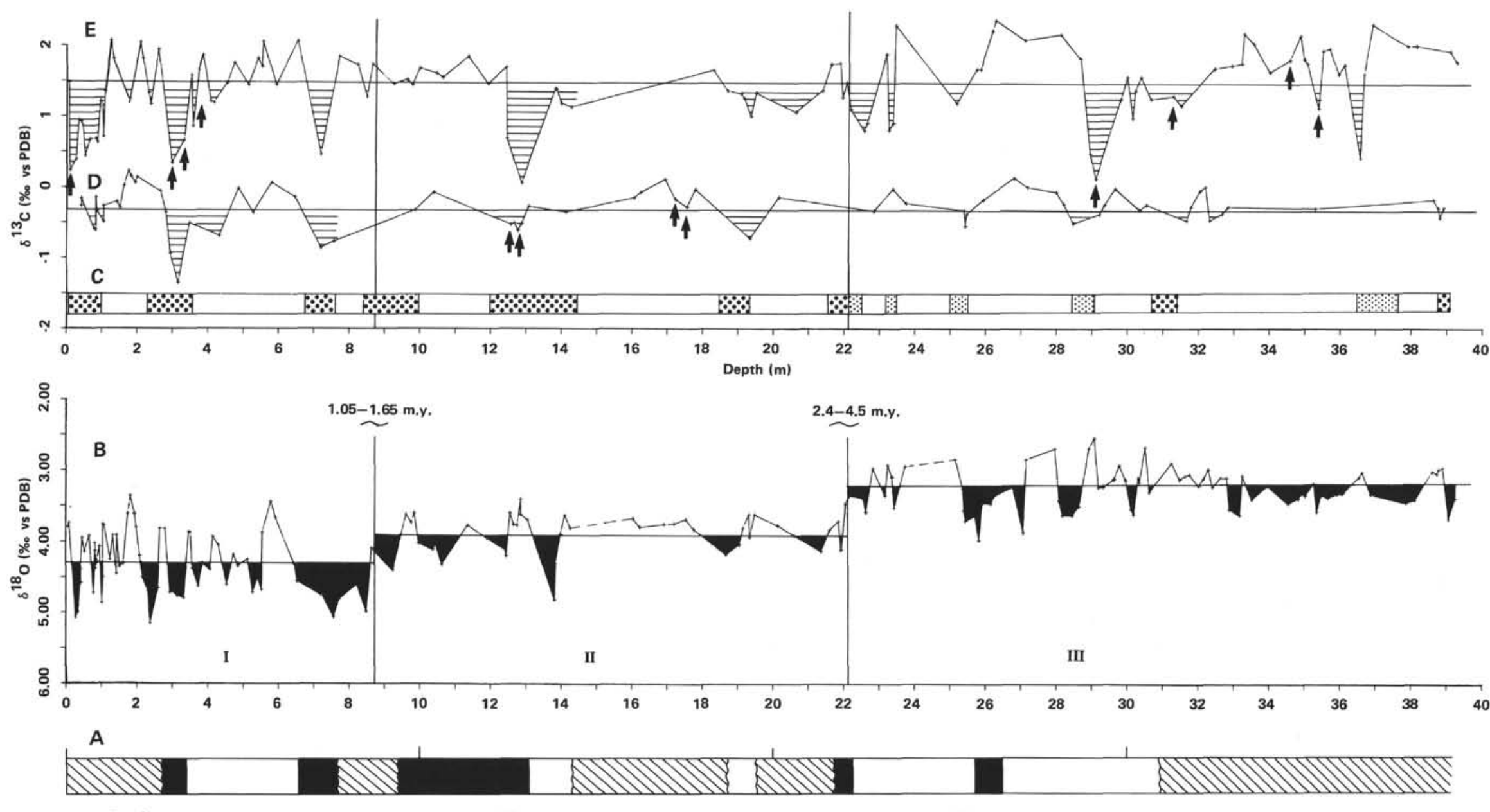

\section{Brunhes}

Matuyama

Gilbert

Figure 3. Hole 544B. I, II, and III are the major stratigraphic sections listed in Table 2. A. Magnetostratigraphy modified after Channell (this volume). Solid (open) bars indicating normal (reversed) polarity; hachured areas: no data. B. Oxygen isotopic record of benthic foraminifers, adjusted to Uvigerina. C. Sediment sections with weak (small dots) and strong (large dots) calciumcarbonate minima relative to the neighbor core sections. D. Carbon isotopic record of $U$. peregrina and $C$. wuellerstorf $i$ adjusted to $U$, peregrina). E. Carbon isotopic record of $P$. murrhina. Arrows indicate phases of fluvial sediment supply as deduced from the relative excess of clay (see Koopmann, 1981). Hachured areas mark distinct $\delta^{13} \mathrm{C}$ minima. 
Table 2. Range of oxygen-isotopic and sedimentary variations in the three major stratigraphic sections of Hole 544B.

\begin{tabular}{|c|c|c|c|c|c|c|c|c|c|}
\hline \multirow{2}{*}{\multicolumn{2}{|c|}{$\begin{array}{l}\text { Section } \\
\text { (m) }\end{array}$}} & \multicolumn{2}{|r|}{$\begin{array}{l}{ }^{18} \mathrm{O} \\
(\%(\%)\end{array}$} & \multicolumn{2}{|c|}{$\begin{array}{c}\text { Carbonate } \\
(\%)\end{array}$} & \multicolumn{2}{|c|}{$\begin{array}{l}\text { Chlorite/ } \\
\text { Kaolinite }\end{array}$} & \multicolumn{2}{|c|}{$\begin{array}{l}\text { Terrigenous } \\
\text { fraction } \\
(\% />2 \mu \mathrm{m})\end{array}$} \\
\hline & & Mean & Range & Mean & Range & Mean & Range & Mean & Range \\
\hline I & $0.0-8.7$ & 4.3 & $\begin{array}{l}3.36-5.15 \\
(\Delta=1.79)\end{array}$ & 60.0 & $\begin{array}{l}39.0-76.8 \\
(\Delta=37.8)\end{array}$ & 3.3 & $\begin{array}{l}1.25-4.74 \\
(\Delta=3.49)\end{array}$ & 35.0 & $\begin{array}{l}25.1-40.9 \\
(\Delta=15.8)\end{array}$ \\
\hline II & $8.7-22.1$ & 3.9 & $\begin{array}{l}3.41-4.82 \\
(\Delta=1.41)\end{array}$ & 60.0 & $\begin{array}{l}51.6-69.6 \\
(\Delta=18.0)\end{array}$ & 3.8 & $\begin{array}{l}2.73-6.00 \\
(\Delta=3.27)\end{array}$ & 35.0 & $\begin{array}{l}29.7-41.5 \\
(\Delta=11.8)\end{array}$ \\
\hline III & $22.1-39.3$ & 3.2 & $\begin{array}{l}2.54-3.97 \\
(\Delta=1.43)\end{array}$ & 75.0 & $\begin{array}{l}60.6-84.4 \\
(\Delta=23.8)\end{array}$ & 2.4 & $\begin{array}{l}0.78-3.59 \\
(\Delta=2.81)\end{array}$ & 30.0 & $\begin{array}{l}27.0-33.5 \\
(\Delta=6.5)\end{array}$ \\
\hline
\end{tabular}

Note: $\Delta=$ difference between maximum and minimum values.

Table 3. Biostratigraphic first appearance datums (FAD) and extinction levels (LAD) for Hole 544B.

\begin{tabular}{lclr}
\hline $\begin{array}{c}\text { Sample } \\
\text { interval } \\
(\mathrm{cm})\end{array}$ & $\begin{array}{c}\text { Sub-bottom depth } \\
(\mathrm{m})\end{array}$ & \multicolumn{1}{c}{ Species/Zone } & $\begin{array}{c}\text { Age } \\
(\mathrm{m} . \mathrm{y})\end{array}$ \\
\hline $1-1,9-11$ & 0.10 & Dominant Emiliania huxleyi & $0.07^{\mathrm{a}}$ \\
$4-1,16-18$ & 11.37 & FAD G. truncatulinoides & $1.90^{\mathrm{c}}$ \\
$6-1,62-64$ & 20.63 & NN 16 & $>2.30^{\mathrm{b}}$ \\
$6-3,37-39$ & 22.18 & LAD G. margaritae & $3.40^{\mathrm{d}}$ \\
$6-3,75-77$ & 22.56 & LAD Globigerina nepenthes & $3.80^{\mathrm{d}}$ \\
$6-3,83-85$ & 22.64 & LAD G. altispira & $2.90^{3}$ \\
$6-3,144-146$ & 23.25 & NN 12 & $>4.60^{\mathrm{b}}$ \\
$12-1,4-6$ & 38.91 & FAD G. margaritae & $5.60^{\mathrm{d}}$
\end{tabular}

Note: Determinations by E. Martini (Frankfurt), U. Pflaumann, and C. Samtleben (Kiel). Absolute ages after Gartner, 1977 ${ }^{\mathrm{a}}$, Haq and Berggren, $1978^{b}$, Berggren et al., $1980^{c}$, and Thunell, $1981^{d}$. rigenous fraction coarser than $2 \mu \mathrm{m}, 6 \mu \mathrm{m}$, and $20 \mu \mathrm{m}$ ). This relationship holds particularly true for the major long-term change of sediment properties at $22.1 \mathrm{~m}$ subbottom depth (Table 2). The grain-size data of the carbonate-free sediment proportion almost exactly match the grain-size distribution of terrigenous sediments because the content of biogenic opal $>6 \mu \mathrm{m}$ is negligible at Hole 544B (0.04 to $0.15 \%$ of the carbonate-free sediment fraction $<63 \mu \mathrm{m}$ ).

The terrigenous sediment fraction is further characterized by its clay-mineral composition. Illite comprises 59 to $75 \%$ of total clay (Fig. 7). The chlorite to kaolinite ratio is plotted separately in Figure 6 because its distribution pattern in surface sediments from the eastern Atlantic is an indicator of sediment input from the Atlas Mountains (Lange, 1982). Indeed, the value nearest to

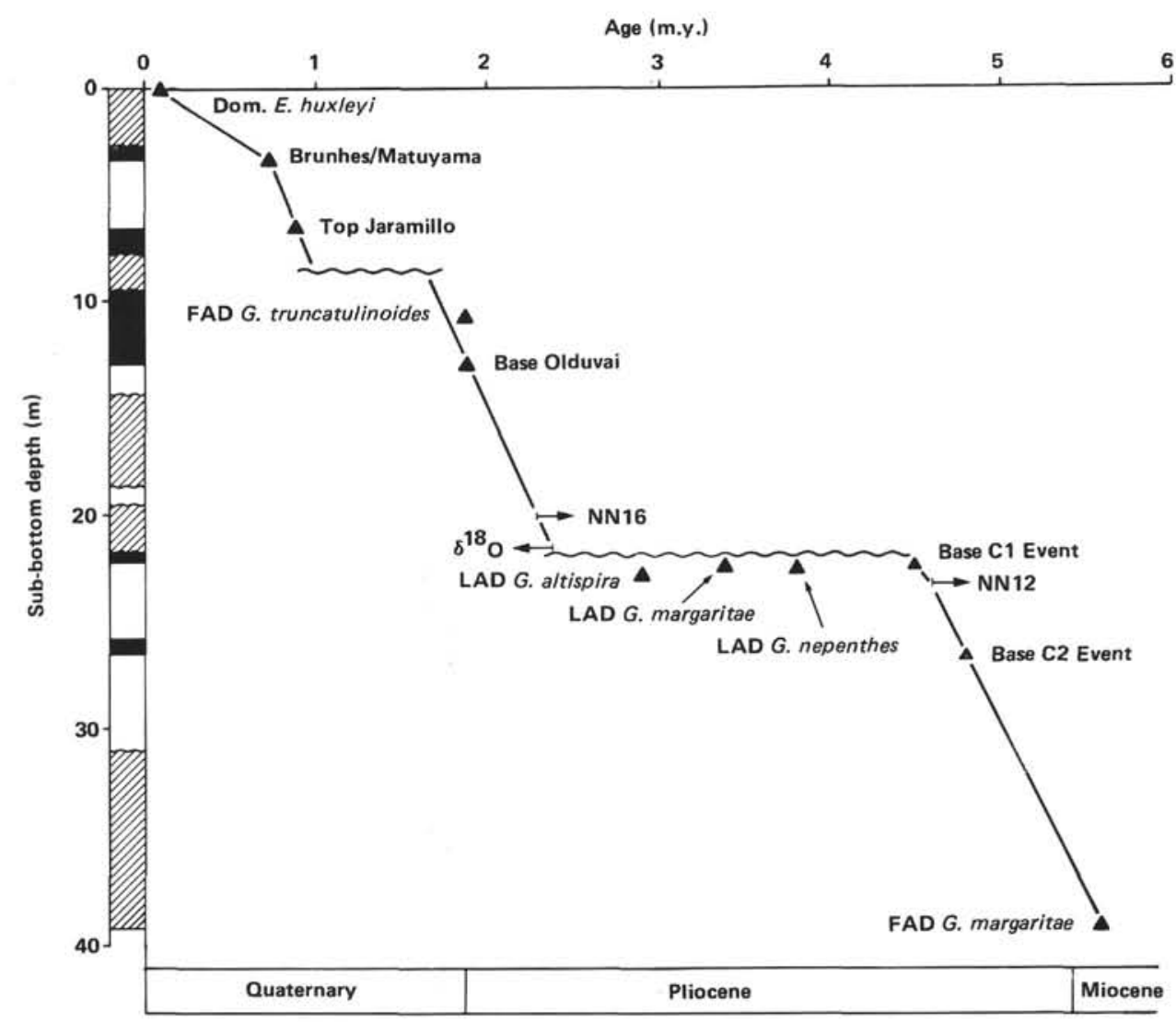

Figure 4. Hole 544B age-depth curve. Magnetostratigraphy modified after Channell (this volume). First and last appearance datums as listed in Table 3. 
NEOGENE OXYGEN-ISOTOPE STRATIGRAPHY AND FLUX RATES

Table 4. Thickness and duration of sediment cycles (Fig. 2).

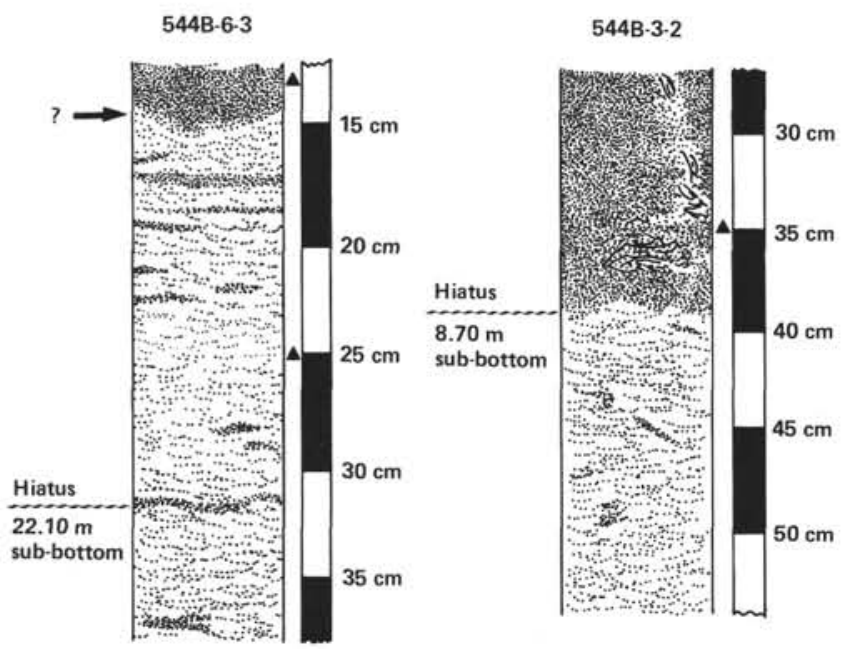

Figure 5. Color changes from brown (dark) to white pinkish (light) sediments at the hiatuses near $22.1 \mathrm{~m}$ and $8.7 \mathrm{~m}$ sub-bottom depth. ? marks possible erosion structure; $\boldsymbol{\Delta}=$ sample positions.

\begin{tabular}{|c|c|c|c|}
\hline \multicolumn{2}{|c|}{ Stratigraphic sections } & \multicolumn{2}{|c|}{ Sediment cycles } \\
\hline $\begin{array}{l}\text { Sub-bottom depth } \\
\text { (m) }\end{array}$ & $\begin{array}{c}\text { Age } \\
\text { (m.y.) }\end{array}$ & $\begin{array}{l}\text { Thickness } \\
\text { (cm) }\end{array}$ & $\begin{array}{l}\text { Duration } \\
\text { (yr.) }\end{array}$ \\
\hline $0.0-3.4$ & $0.10-0.73$ & $75-130$ & $140,000-240,000$ \\
\hline $3.4-8.7$ & $0.73-1.05$ & $32-105$ & $19,000-62,500$ \\
\hline $8.7-22.1$ & $1.65-2.40$ & $20-75$ & $12,00045,000$ \\
\hline $22.1-31.3$ & $4.50-5.10$ & $20-75$ & $12,000-45,000$ \\
\hline$>31.3$ & $>5.10$ & & o cycles \\
\hline
\end{tabular}

the surface at Hole 544B (ratio of 2.3 from stage 5 interglacial sediments) matches almost exactly the number proposed for the site position by Lange's (1982) distribution pattern of the present interglacial sediments. Compared to this value, the chlorite to kaolinite ratio almost tripled to about 6 during late Pliocene and Quaternary cold stages and halved to about 1 during some extreme warm stages. Below $22.1 \mathrm{~m}$ depth, the ratio decreases to a low of 0.8 , which resembles a clay-mineral composition found much further west or south of the present area receiving the maximum amount of Atlas-derived

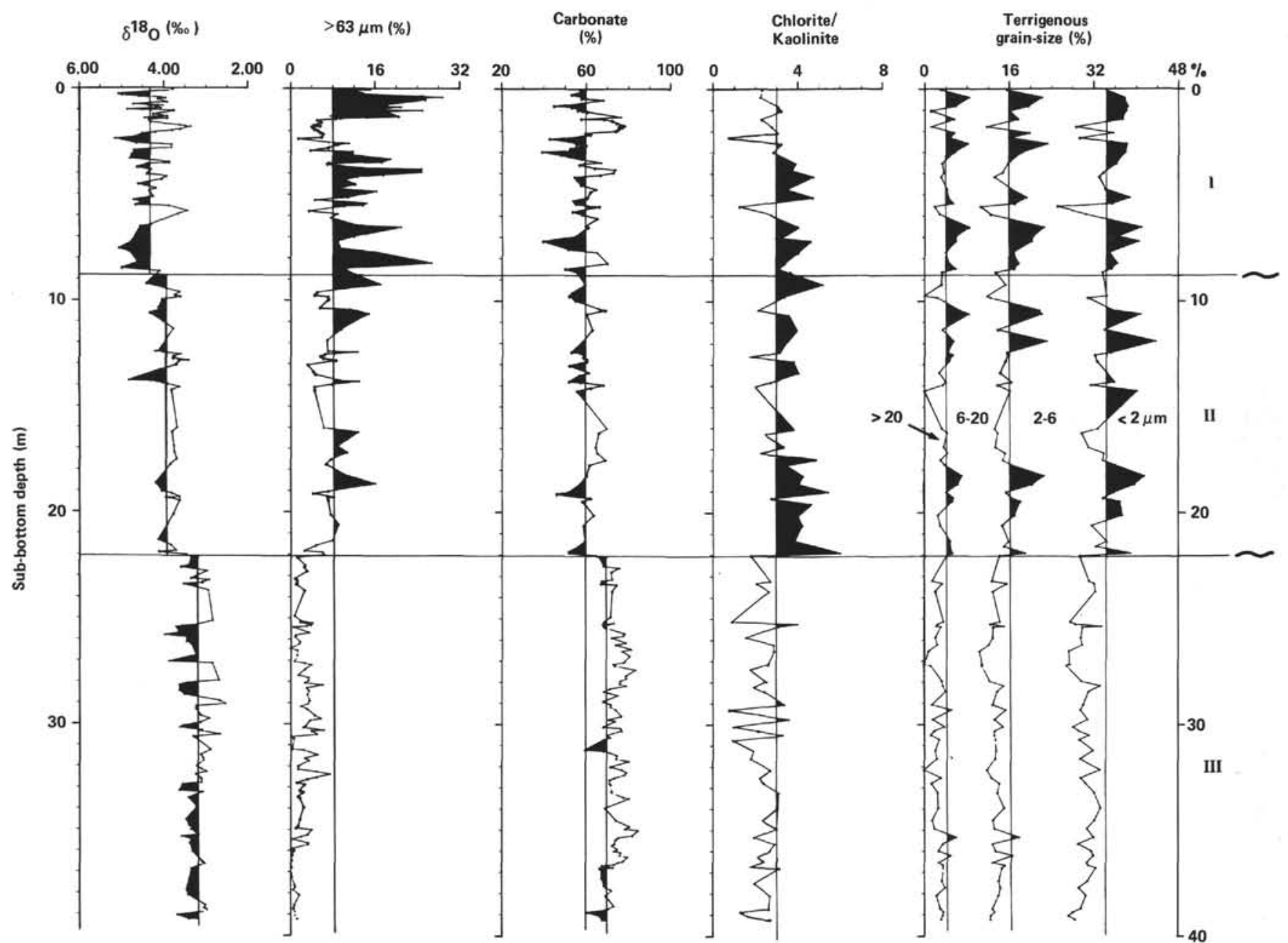

Figure 6. Hole 544B oxygen isotopic and sedimentary record. $\%>63 \mu \mathrm{m}$ refers to the total sediment samples, grain-size classes on the right side of the figure refer to the carbonate-free sediment residue. 


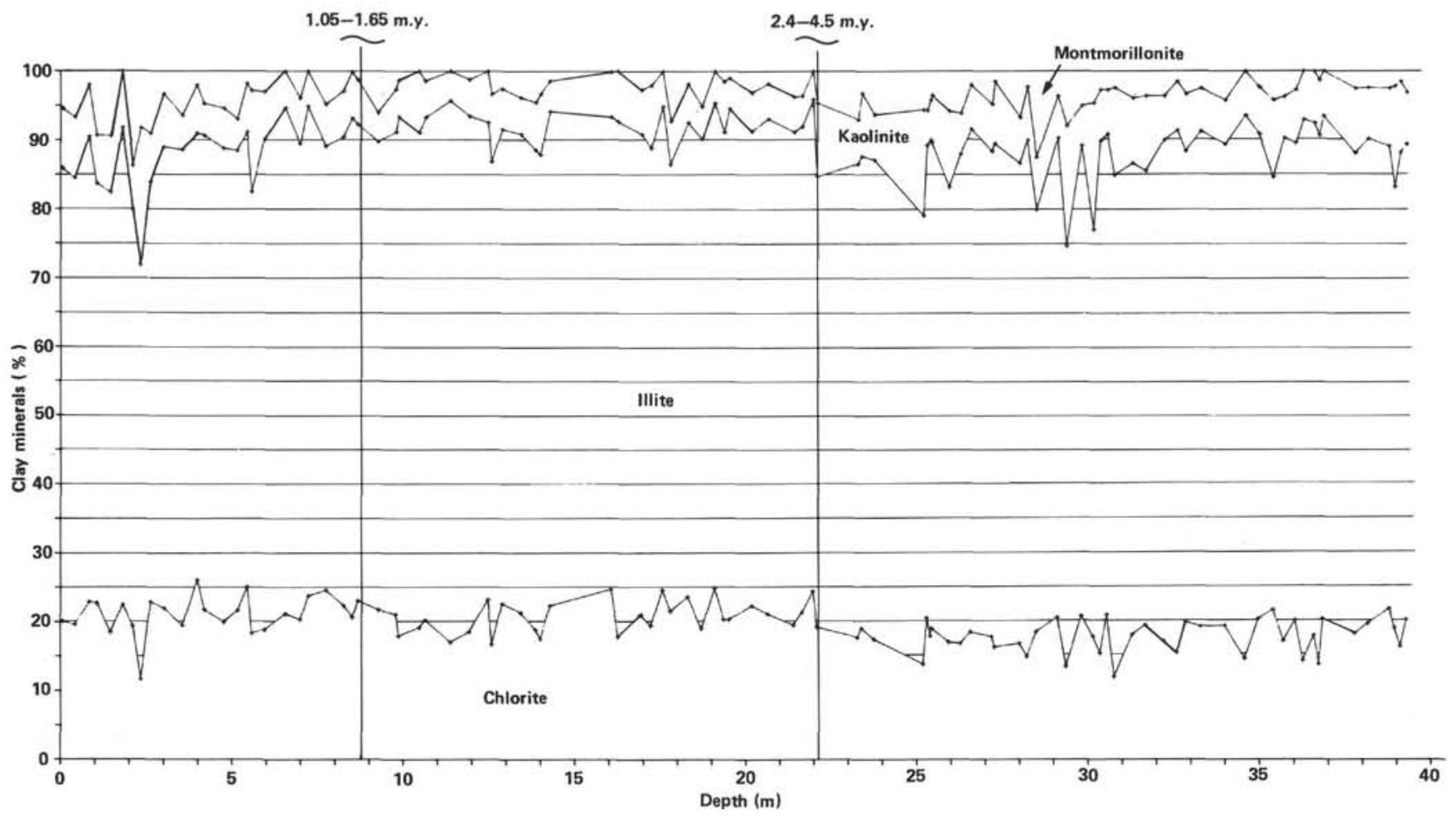

Figure 7. Clay-mineral composition of sediments at Hole 544B.

chlorite (Lange, 1982). Therefore, the low ratio corresponds to the one found near the Canary Islands, an area with dust falls of greater south Saharan origin. The fluctuations in the chlorite to kaolinite ratio closely parallel the fluctuations in the oxygen isotopic composition with low chlorite/kaolinite values corresponding to light isotopic ratios (Fig. 6). In summary, the abrupt changes of all sediment variables near $22.1 \mathrm{~m}$ sub-bottom depth clearly corroborate our assumption of a major hiatus at this level. At the same time, they reflect a major climatic change that resulted in a drastic increase of physical weathering in the nearby Atlas Mountains coinciding with a general growth of glaciation in the Northern Hemisphere and a lowering of the sea level (Backman, 1983). No change in the clay-mineral and grain-size composition occurs near the end of the Messinian at about $32 \mathrm{~m}$ sub-bottom depth (Fig. 6).

The rates of terrigenous sediment accumulation (Fig. 8) vary between 0.15 and $1.13 \mathrm{~g} / \mathrm{cm}^{2} \cdot 10^{3} \mathrm{yr}$. and are generally low when compared to the Recent and late Pleistocene rates off Mauretania $\left(1.0\right.$ to $5.0 \mathrm{~g} / \mathrm{cm}^{2} \cdot 10^{3} \mathrm{yr}$.); Koopmann, 1981). They are low following the BrunhesMatuyama boundary (3.40 m sub-bottom depth) and prior to $4.5 \mathrm{~m} . \mathrm{y}$. (22.1 m sub-bottom depth). The rates of calcium-carbonate deposition vary from 0.25 to 1.65 $\mathrm{g} / \mathrm{cm}^{2} \cdot 10^{3} \mathrm{yr}$. and indicate a decrease of the pelagic carbonate flux from early Pliocene to middle Quaternary times, particularly after the Brunhes-Matuyama boundary at $0.73 \mathrm{~m} . y$. In principle, the reduction of the carbonate flux is a result of increased calcium-carbonate dissolution near $3600 \mathrm{~m}$ water depth, of decreased calcium-carbonate production, or of current-induced winnowing of (fine-grained) calcium carbonate. The last model

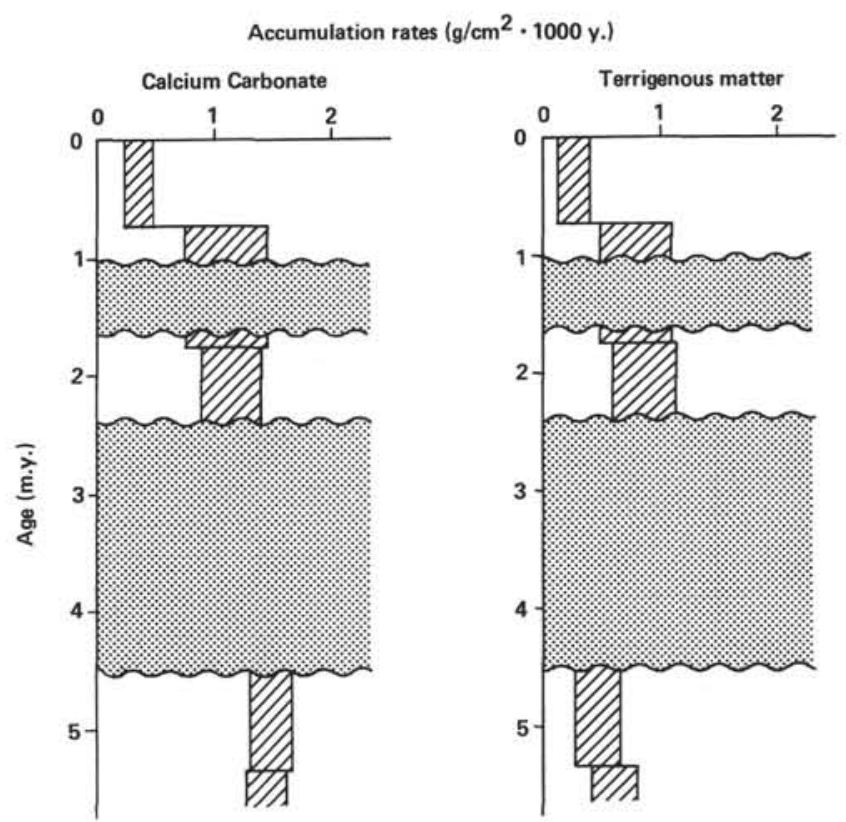

Figure 8. Bandwidth of carbonate and carbonate-free (terrigenous) sediment accumulation rates. Dotted intervals are hiatuses.

appears to be the most important explanation because the decrease of calcium-carbonate flux during the Quaternary is paralleled by both high values of the (mainly planktonic foraminifers) coarser than $63 \mu \mathrm{m}$ fraction (Fig. 6) and a marked decrease of terrigenous flux (Fig. 8). Occasionally, the winnowing has progressed to erosion as shown by the two hiatuses, possibly controlled by 
contour currents (Sarnthein et al., 1982). In addition, calcium-carbonate dissolution may have influenced the reduction of carbonate flux where intervals of reduced calcium carbonate coincide with low ${ }^{13} \mathrm{C} /{ }^{12} \mathrm{C}$ ratios (Figs. $3 \mathrm{C}-3 \mathrm{E})$. These low values are generally regarded as a result of an advection of aged, i.e., oxygen-poor and $\mathrm{CO}_{2}$-rich, deep water masses that promote dissolution of calcium carbonate (Blanc and Duplessy, 1982). However, $\mathrm{CO}_{2}$ and ${ }^{12} \mathrm{C}$-enriched deep water may also be produced by a local excess of organic matter. This may be due to locally high plankton productivity such as that induced by the nutrients supplied by river mouths near the continent. Indeed, phases of fluvial sediment supply from the Atlas Mountains parallel $\delta^{13} \mathrm{C}$ minima in a number of cases (Figs. 3C-3E) (details in Stein, 1984) and, at the same time, indicate humid climate intervals in north Africa.

\section{CONCLUSIONS}

1. Hole 544B comprises a sediment section between 0.1 and $5.6 \mathrm{~m}$.y. which is incomplete due to two major stratigraphic gaps near 1.05 to 1.65 m.y. and 2.4 to 4.5 m.y.

2. Distinct color cycles, generally 20 to $100 \mathrm{~cm}$ thick, characterize most of the sediment section (except for its deepest proportion). The cycles comprise sediment intervals of some 20,000 and $40,000 \mathrm{yr}$. and, therefore, may reflect the persisting time control by fluctuations of solar insolation. There is no explanation as to why the cycles disappear prior to $5.1 \mathrm{~m} . \mathrm{y}$.

3. Major stratigraphic events are depicted by distinct overall shifts in oxygen-isotope composition and, partly, by stratigraphic gaps. The end of the Messinian salinity crisis (5.2 m.y.) is marked by decreasing $\delta^{18} \mathrm{O}$ values, but no other indication of paleoclimatic change, except for the onset of the visually determined sediment cycles. The mid-Pliocene global deterioration of climate prior to 2.4 m.y. has caused the most drastic long-term shift of $\delta^{18} \mathrm{O}$ values $\left(\Delta \delta^{18} \mathrm{O}=0.7 \%\right)$. The shift appears exaggerated by an associated hiatus that may indicate a phase of general erosion due to strengthened contour currents along the northwest African continental margin, also observed in the neighboring DSDP Site 397. At the same time, enhanced terrigenous deposition rates and increasing terrigenous grain-sizes and proportions of chlorite reflect strong changes in the local sedimentary regime promoting a more rapid denudation of the adjacent Atlas Mountains by a climate conducive to physical weathering. In addition, a generally lowered sea level resulted in the shelf drying up and thereby contributed to the sediment transfer from the continent to the deep sea. A similar, but weaker, event took place near 1.05 m.y. (with no associated changes in the clay-mineral or grain-size composition) and initiated the genuine sedimentary regime of the Quaternary.

\section{ACKNOWLEDGMENTS}

We thank T. Allert, J. Mienert, D. Mueller, and M. Stransky (Kiel) for technical assistance and the DSDP core curator for providing abundant sample material. Dr. J. Channell kindly provided unpublished magnetostratigraphic data. Dr. H. Lange (Kiel) contributed to the discussion of the clay-mineral composition. We are grateful to Drs. E.
Martini (Frankfurt), U. Pflaumann, and C. Samtleben (Kiel) for supplying some crucial biostratigraphic data and particularly to R. Zahn for performing the oxygen and carbon isotope measurements. We thank our reviewers, especially Walter Dean, for their numerous constructive suggestions for improvement of the manuscript. Support of the Deutsche Forschungsgemeinschaft is gratefully acknowledged.

\section{REFERENCES}

Agwu, C., and Beug, H.-J., 1982. The history of the vegetation and climate as recorded in marine sediments off the west African coast. Meteor Forsch. Ergebn., C, 36:1-30.

Backman, J., 1983. The age of the first cycle of ice-rafted debris in the North Atlantic Ocean. Terra Cognita, 3(no. 2-3):221.

Berger, A. L., 1978. Long-term variations of caloric insolation resulting from the earth's orbital elements. Quat. Res., 9:139-167.

Berggren, W. A., Burckle, L. H., Cita, M. B., Cooke, H. B. S., Funnel, B. M., Gartner, S., Hays, J. D., Kennett, J. P., Opdyke, N. D., Pastouret, L., Shackleton, N. J., and Takayanag, Y., 1980. Towards a Quaternary time scale. Quat. Res., 13:277-302.

Biscaye, P. E., 1965. Mineralogy and sedimentation of recent deep sea clay in the Atlantic Ocean and adjacent seas and oceans. Bull. Geol. Soc. Am., 76:803-832.

Blanc, P., 1981. Paléoclimatologie isotopique et histoire de l'eau profonde Atlantique depuis 15 millions d'années [Thesis]. University Paris XI-Orsay, Paris.

Blanc, P., and Duplessy, J.-C., 1982. The deep water circulation during the Neogene and impact of the Messinean salinity crisis. Deep Sea Res., in press.

Cita, M. B., and Ryan, W. B. F., 1979. Late Neogene environmental evolution. In von Rad, U., Ryan, W. B. F., et al., Init. Repts. DSDP, 47, Pt. 1: Washington (U.S. Govt. Printing Office), 447-459.

Ganssen, G., 1983. Dokumentation von Kuestenauftrieb anhand stabiler Isotope in rezenten Foraminiferen vor Nordwest-Afrika. Meteor Forsch. Ergebn. C., 37:1-46.

Gartner, S., 1977. Calcareous nannofossil biostratigraphy and revised zonation of the Pleistocene. Mar. Micropaleont., 2:1-25.

Hamilton, N., 1979. A paleomagnetic study of sediments from Site 397 northwest African continental margin. In von Rad, U., Ryan, W. B. F., et al., Init. Repts. DSDP, 47, Pt. 1: Washington (U.S. Govt. Printing Office), 463-477.

Haq, B. U., and Berggren, W. A., 1978. Late Neogene calcareous plankton biochronology of the Rio Grande Rise (South Atlantic Ocean). J. Paleont., 52:1167-1194.

Hinz, K., Winterer, E. L., Baumgartner, P. O., Bradshaw, M. J., Channel, J. E. T., Jaffrezo, M., Jansa, L. F., Leckie, R. M., Moore, J. N., Rullkötter, J., Schaftenaar, C., Steiger, T. H., Vuchev, V., and Wiegand, G. F., 1982. Preliminary results from DSDP Leg 79 seaward of the Mazagan Plateau off central Morocco. In von Rad, U., Hinz, K., Sarnthein, M., and Seibold, E. (Eds.), Geology of the Northwest African Continental Margin: Berlin (Springer Verlag), pp. 23-33.

Koopmann, B., 1981. Sedimentation von Saharastaub im subtropischen Nordatlantik während der letzten 25000 Jahre. Meteor Forsch. Ergebn., C., 35:23-59.

Lange, H., 1982. Distribution of chlorite and kaolinite in eastern Atlantic sediments off North Africa. Sedimentology, 29:427-431.

Lutze, G. F., 1979. Benthic foraminifers at Site 397: faunal fluctuations and ranges in the Quaternary. In von Rad, U., Ryan, W. B. F., et al., Init. Repts. DSDP, 47, Pt. 1: Washington (U.S. Govt. Printing Office), 419-431.

Müller, G., 1967. Methods in sedimentary petrology. In von Engelhardt, W., Füchtbauer, H., and Müller, G. (Eds.), Sedimentary Petrology, Part I: Stuttgart (Schweizerbart'sche Verlagsbuchhandlung).

Sarnthein, M., Thiede, J., Pflaumann, U., Erlenkeuser, H., Fütterer, D., Koopmann, B., Lange, H., and Seibold, E., 1982. Atmospheric and oceanic circulation patterns off northwest Africa during the past 25 million years. In von Rad, U., Hinz, K., et al. (Eds)., Geology of the Northwest African Continental Margin: Berlin (Springer Verlag), pp. 545-604.

Shackleton, N. J., 1973. Attainment of the isotopic equilibrium between ocean water and the benthonic foraminifera genus Uvigeri$n a$ : Isotopic changes in the ocean during the last glacial. Coll, Int. CNRS, 219:203-209.

Shackleton, N. J., and Cita, M. B., 1979. Oxygen and carbon isotope stratigraphy of benthic foraminifers at Site 397: detailed history of 
climatic change during the late Neogene. In von Rad, U., Ryan, W. B. F., et al., Init. Repts. DSDP, 47, Pt 1: Washington (U.S. Govt. Printing Office), 433-445.

Shackleton, N. J., and Opdyke, N. D. 1973. Oxygen isotope and paleomagnetic stratigraphy of equatorial Pacific core V28-238: oxygen isotope temperatures and ice volumes on a $10^{5}$ year scale. Quat. Res., 3:39-55.

Seibold, E., 1982. The Northwest Continental Margin-an introduction. In von Rad, U., Hinz, K., et al. (Eds.), Geology of the Northwest African Continental Margin: Berlin (Springer Verlag), pp. 3-20.

Stein, R., 1984. Zur neogenen Klimaentwicklung in Nordwest-Afrika und Palaeo-Ozeanographie im Nordost-Atlantik: Ergebnisse von DSDP-Sites 141, 366, 397 und 544B [Thesis]. Berichte-Reports, Geol. Palaeont. Inst. Univ. Kiel, Nr. 4. in press. Rapid grain-size analyses of silt and clay fractions by SediGraph 5000D: Comparison with Coulter Counter and Atterberg methods. J. Sed. Petrol.

Stein, R., and Sarnthein, M., in press. Late Neogene events of atmospheric and oceanic circulation offshore northwest Africa: highresolution record from deep-sea sediments. Palaeoecology of Afri$\mathrm{ca}$, Vol. 16.

Thunell, R. C., 1981. Late Miocene-early Pliocene planctonic foraminiferal biostratigraphy and paleoceanography of low-latitude marine sequences. Mar. Micropaleont., 6:71-90.

Date of Initial Receipt: January 19, 1983

Date of Acceptance: October 25, 1983 